\title{
Methodological Approaches to Funding Tertiary Education Institutions Given the Relationship between GDP and Budget Expenditure on Education
}

\author{
Lyudmila Oleynikova* \\ Department of Fiscal policy and tax \\ regulation \\ Academy of Financial Management \\ Kyiv, Ukraine \\ oleynikova.mila@ukr.net
}

Lilya Mykhailyshyn

Department of International

Economic Relations

Vasyl Stefanyk Precarpathian

National University

Ivano-Frankivsk, Ukraine

https://orcid.org/0000-0001-7944-5317

\author{
Valentyna Helman \\ Personnel management and marketing \\ department \\ Zaporizhzhia National University \\ Zaporizhzhia, Ukraine \\ smsvell@yandex.ua
}

Roman Kravchuk

Department of Applied Economics

Ivano-Frankivsk National Technical

University of Oil and Gas

Ivano-Frankivsk, Ukraine

romanmaster2005@gmail.com

\author{
Brych Vasyl \\ Department of International Tourism \\ and Hospitality Business \\ Ternopil National Economic University \\ Ternopil, Ukraine \\ http://orcid.org/0000-0002-4277-5213
}

\begin{abstract}
The main issues of funding tertiary education in the EU in the light of the tertiary education system role in shaping Europe-2020 strategy were investigated. The methods of using the mechanisms of the formula model for tertiary education institutions funding were considered. The importance of methods and forms of funds allocation to universities depending on ownership forms was substantiated. The methodological approaches to financial support of tertiary education institutions in the $\mathrm{EU}$ were defined. The existing experience of European countries with regard to the possibility of financial autonomy of European tertiary education institutions was studied. The structure of expenditure on tertiary education in the countries of the world and Ukraine was established. State expenditure on tertiary education (bachelor, master and doctoral programmers, including research and implementation of scientific developments) in \% of the GDP was distinguished. The balance between public and private funding of tertiary education in different OECD countries and Ukraine as well as allocation of expenditure on tertiary education in Ukraine by funding sources were presented. The model of correlative linear regression dependence of the GDP on the budget expenditure on education was built, and the direct dependence between the indices was revealed.
\end{abstract}

Keywords-expenditure structure, budget, balance, methods, mechanisms, funding sources, consolidated budget, GDP.

\section{INTRODUCTION}

In Ukraine, the issue of funding tertiary education institutions (TEIs) as well as benefits for individual taxes and fees are closely related to the status of such entities, their form of ownership and activities carried out. Special attention should be paid to the fact that today the legislation provides for three forms of ownership for TEIs, namely state, municipal and private forms [1]. According to the Budget Code of Ukraine, state and municipal TEIs are budgetary institutions, which significantly limits the opportunities for their economic activities. Here, we should refer to the definition of "budgetary institution", as according to Article 2 of the Budget Code of Ukraine, it is a body, institution or entity defined by the Constitution of Ukraine, an institution or organization created in the established procedure by bodies of state power or bodies of local self-government, which is fully funded from the state or local budgets respectively. In terms of taxation, budgetary institutions are non-profitable and are defined by the Budget Code of Ukraine (14.1.17. budgetary institution - in the meaning given in the Budget Code of Ukraine).

The concept of "non-profit organization" is defined by the Tax Code of Ukraine. Thus, sub-section 133.4.6 of Article 133 says that non-profit organizations that meet the requirements and are not tax payers can be classified as budgetary institutions. According to sub-section 14.1.121 of the Tax Code, non-profit entities are enterprises, institutions and organizations, which are not payers of the corporate income tax in accordance with section 133.4 of the Tax Code of Ukraine. According to sub-section 133.4.2, income (profits) of non-profit organization must be used exclusively to finance expenditure on maintenance of a non-profit organization, implementation of the purpose (goals, objectives) and performance of activities specified in its constituent documents and is not intended to obtain material benefits. Tertiary education funding in the EU is viewed in the light of the tertiary education system role in shaping Europe-2020 strategy, where the main issues are as follows: the need to increase state funding of tertiary education; creation of conditions for greater autonomy in management of own financial resources of tertiary education institutions; promotion of diversification of funding sources and partnerships with research institutions, enterprises and regional authorities [2].

Therefore, the issue of building the correlation field, which will enable us to graphically evaluate the correlation between GDP volume rates and consolidated budget expenditure on education during 2006-201, is of relevance. 


\section{ANALYSIS OF RECENT RESEARCH AND PUBLICATIONS}

Currently, one of the most relevant and acute problems for our country is the issue of stimulating economic growth on an innovative basis, which also causes provision of state funding and support for development of scientific activities. The complex issues of science and education funding, which are typical of the country today and are accompanied by significant budget constraints for support of scientific capacity and funding of science development, are being researched by many domestic scholars, namely: Yefymenko T. I. [3, 4], Ivanov Yu. B. [4], Kotykova O. I. [5], Londar S. L. [4], and others.

\section{RESULTS}

The income structure of public tertiary education institutions in Europe is divided into the following main areas: state budget allocations, which at the European level make up from $50 \%$ to $90 \%$ of the TEI total income; tuition fees paid by students (household expenditure), whose amount depends on the policy of tertiary education funding, which is implemented at the national level. According to the EUA 12 study, European countries fall into two main categories: the first category includes countries where the tuition fee accounts for approximately 5\% of total income (e.g. North European countries, Austria, Belgium, the Czech Republic, France, Germany, Estonia), while the second category includes countries where the tuition fee makes up approximately $10 \%$ of total income and in some cases even more (e.g. Hungary, Ireland, Italy, the Netherlands, Latvia, Poland, Slovakia, Spain, the UK); other private sources of income: financing under contracts with the business sector, research grants, provision of services in various fields, European funding and other non-budgetary sources. In some EU countries, such sources provide up to $10 \%$ of the total amount of funding for tertiary education [6].

The activities of public tertiary education institutions in Europe are financed from both public and private funds. A significant share of public funding in tertiary education revenues increases the importance of methods and forms of funding allocation to universities. According to various studies $[7 ; 8 ; 9]$ conducted at the EU level, there are several main forms of attracting financial resources by universities and different methods of allocating their funding. The main ones are as follows. A block grant (subsidy), which covers tuition costs (courses and seminars/workshops), administrative costs, and/or research costs. A university can decide independently how to use this funding according to its needs. In almost all EU Member States (26 countries), universities receive public funding in the form of block grants, which they can use for their internal activities. Within the framework of university autonomy, most countries impose stricter restrictions on the structure of grants for internal needs (personnel, equipment, infrastructure, research and training). Only eight countries (Austria, Belgium, Estonia, Norway, Poland, Slovakia, Switzerland and the UK) have universities with no restrictions regarding the way they spend allocated resources. The grant amount can be determined in various ways: through negotiations, according to a funding formula or on a historical basis. The distribution of block grants by formula is the primary method of state funds allocation to public tertiary education institutions and is used in the majority of countries, for instance, those included in the study of university autonomy in Europe [10].

Block grant funding, defined through agreements and negotiations between the institution and the relevant Ministry, is used in some countries, such as Austria, Germany and Spain. Budget funding with expenditure breakdown by items, under which universities receive their funding. The decision on allocation is made by the relevant Ministry or Parliament. Consequently, universities cannot decide on the distribution of such revenues or can do it with certain restrictions. This funding form is widely used in Eastern European countries: Bulgaria, Cyprus, Greece, Lithuania, Latvia, Serbia and Turkey [2].

It should be noted that in recent years in Eastern Europe there has been a trend towards an increase of funding on the basis of block grants rather than on the basis of line item budgets which results in an increase of university autonomy in the use of revenues attracted. At the European level, there are different ways of public funds allocation to universities: formula-based funding (funding based on the results, goal funding (on an application principle after agreeing on the terms), on a historical basis); result-based funding; objective funding; competitive funding. European practice shows that such methods of funding allocation are used in combination (for instance, part of the block grant is determined by the funding formula, part - through agreed applications, and the rest can be determined on a historical basis).

The formula model of funding allocation [11] is defined as an algorithm based on standard criteria for calculating the amount of state grants allocated to tertiary education institutions (for teaching and/or operational activities, and in some cases for research). In practice, there are several methods used to describe the mechanisms of the formula funding model, in particular: student-based funding, teaching funding, marginal cost model or standard cost-based funding formula, etc.

Some studies $[12 ; 13 ; 14 ; 15]$ describe two types of such models in respect with the category of indices/criteria used in the formula: consumption-oriented funding: formulas, which take into account input data (such as, a number of employees or their wages, number of employees with a $\mathrm{PhD}$, number of bachelors, masters, etc.) are used. Most often, such formula is used to calculate funding based on the allocation of teaching costs. Currently, the use of the criterion of a teaching staff number in Europe is less significant; most countries use expenditure calculation according to the number of students [16]; goal-oriented funding (output data): formulas, which take into account performance (such as, a number of student loans accumulated, number of undergraduate and/or master program graduates, employed graduates, number/percentage of graduates employed according to their specialization, etc.) are used. This is an innovative type of funding in the context of the current trend of "new public administration", and it provides a much better equilibrium between allocated funding and expected university performance. However, the debates conducted in the European Union point out the difficulties [16] universities are faced with in terms of the performance measurement accuracy, which affects achievement of longterm goals. 
In practice, funding formulas in education tend to use different approaches, applying the criteria of input data and performance results, most often a number of admitted students and number of graduate bachelors. Table 1 shows the formulas used in individual EU countries. Higher education funding in Romania includes the following categories of allocations [17]: basic funding is grounded on the standard cost of student training; it is allocated to one person enrolled in public tertiary education institutions for publicly-funded places. Its amount is set based on the number of students, by multiplying by education level coefficients (bachelor programme or master programme), field of study (Medicine, Law, Economics, Natural Sciences, etc.) and language of study. Basic funding covers salaries, operating expenses, maintenance of premises and facilities; supplementary funding is allocated owning to significant achievements of a university, accounts for $30 \%$ of basic funding and is allocated on the basis of performance indices; institutional development fund, which is allocated on a project (competitive) basis; grants for doctoral studies; additional funding (partial): capital investments, financing of dormitories and canteens; scholarships.

The so-called related additional funding (complementary) is only provided to institutions (establishments) and includes partial funding of campus, canteens (allocated according to the number of students), the cost of capital repairs, capital investments. As well, the Ministry directly allocates the budget funds to institutional scholarships. Higher education institutions can use extra-budgetary revenues to fund their educational activities. Education funding sources in Lithuania [18] are the state budget, regional budgets, city budgets, private sources, funds. Allocation of the state budget funds depends on the education level, but as a rule they are directed to funding state-backed TEIs, in some cases - state vocational schools.

Most often, funds of city budgets are allocated to secondary schools and pre-school education institutions. At the same time, funding of religious (confessional) secondary schools, non-formal education institutions (especially preschool) and special education programmes is carried out from private resources. Public, international and private funds can also be sources of education funding. Thus, the above mentioned countries use formula funding, which, however, has very different mechanisms of implementation. In both cases, a certain level of basic funding per student is applied, which can be adjusted. The approaches to correction are rather different, and, in our opinion, Lithuania's approach is more progressive and aimed at stimulating the development of tertiary (higher) education institutions and their competitiveness. The introduction of funding based on results is a way of improving the formula-based funding through consideration of TEIs' specific indices.

Objective funding is another model of direct funding aimed at specific goals generally consistent with projects which are viewed as state priorities by authorities and supported by the goals set at the institutional level. Funding can be allocated on a competitive basis or to some institutions directly, after the application approval and substantiation of the necessary costs. Competitive funding is used to allocate public funds according to the pre-defined criteria, which are used to select and assess the capacity and need to implement specific measures so that they receive funding to achieve specific competitive objectives.

TABLE I. APPROACHES TO UNIVERSITY FUNDING IN LITHUANIA AND ROMANIA

\begin{tabular}{|c|c|c|}
\hline Funding approach & Mechanism & Coefficients \\
\hline \multicolumn{3}{|c|}{ Lithuania } \\
\hline $\begin{array}{l}\text { The TEI budget consists of } \\
\text { "student basket", funds for } \\
\text { maintenance of the university } \\
\text { environment (allocated to } \\
\text { maintenance of buildings, } \\
\text { utilities, salaries of technical } \\
\text { staff, social insurance for } \\
\text { employees and other everyday } \\
\text { operating costs), project funds } \\
\text { (allocated to implementation of } \\
\text { research projects involving } \\
\text { universities/colleges) and } \\
\text { sponsorship. The cost of } \\
\text { education is based on the } \\
\text { student basket (introduced in } \\
\text { 2009 for universities). Tuition } \\
\text { fees for TEIs (universities and } \\
\text { colleges) are set by the } \\
\text { Ministry of Education and } \\
\text { Science. Applicants can } \\
\text { choose a curriculum and } \\
\text { education institution. } \\
\text { Admission to TEIs is based on } \\
\text { the results of state } \\
\text { examinations in secondary } \\
\text { school (so called maturity } \\
\text { exams). The result of the exam } \\
\text { determines the opportunities } \\
\text { for further education for the } \\
\text { student: University or college } \\
\text { tuition fees are paid at the } \\
\text { public expense or from } \\
\text { applicants' private funds. }\end{array}$ & $\begin{array}{l}\text { Student basket is the } \\
\text { annual amount of } \\
\text { resources spent on } \\
\text { training per student } \\
\text { (teachers" salaries, } \\
\text { teaching materials, } \\
\text { management costs, } \\
\text { pedagogical and social } \\
\text { assistance). Student } \\
\text { basket does not } \\
\text { include overhead costs } \\
\text { (payments of technical } \\
\text { workers, costs of } \\
\text { heating, water supply, } \\
\text { etc.). Student basket } \\
\text { includes the funds, } \\
\text { which "follow the } \\
\text { student". }\end{array}$ & $\begin{array}{l}\text { The } \\
\text { coefficients } \\
\text { enable } \\
\text { adjusting the } \\
\text { cost of the } \\
\text { student basket } \\
\text { depending on } \\
\text { the subject } \\
\text { area, } \\
\text { education } \\
\text { level and } \\
\text { territorial } \\
\text { belonging of } \\
\text { the TEI. }\end{array}$ \\
\hline \multicolumn{3}{|c|}{ Romania } \\
\hline $\begin{array}{l}\text { The main principle lies in } \\
\text { combination of the state } \\
\text { authorities' decision on the } \\
\text { number of state-funded places } \\
\text { at higher education institutions } \\
\text { with the budget capacity for } \\
\text { such funding (a so-called } \\
\text { "contractual basis" between } \\
\text { the Ministry and universities) } \\
\text { on the basis of the allocation } \\
\text { formula. } \\
\text { The main allocation criterion is } \\
\text { a number of students enrolled } \\
\text { in budget places on the basis of } \\
\text { multi-year funding. To ensure } \\
\text { transparency and } \\
\text { accountability, the formula is } \\
\text { applied by an independent } \\
\text { organization, the CNFIS (the } \\
\text { National Council for Higher } \\
\text { Education Funding), and } \\
\text { includes basic funding and } \\
\text { supplementary funding. As } \\
\text { well, funding includes } \\
\text { development funds, grants, } \\
\text { capital investments, university } \\
\text { infrastructure funding and } \\
\text { scholarships. }\end{array}$ & $\begin{array}{l}\text { Annually, the } \\
\text { government decides } \\
\text { on the number of } \\
\text { places to be funded } \\
\text { from the state budget } \\
\text { for admission to } \\
\text { bachelor and master } \\
\text { programmes. The } \\
\text { Ministry of Education } \\
\text { distributes budget- } \\
\text { funded places between } \\
\text { universities. } \\
\text { Universities can } \\
\text { independently } \\
\text { distribute the allocated } \\
\text { number of places } \\
\text { between master's } \\
\text { degree programmes } \\
\text { and bachelor's degree } \\
\text { programmes. CNFIS } \\
\text { calculates the final } \\
\text { number of equivalent } \\
\text { students at the } \\
\text { university and country } \\
\text { levels (number of } \\
\text { students } \\
\text { enrolled*equivalence } \\
\text { coefficients). }\end{array}$ & $\begin{array}{l}\text { The } \\
\text { coefficients } \\
\text { enable } \\
\text { adjusting the } \\
\text { standard cost } \\
\text { of training } \\
\text { depending on } \\
\text { the subject } \\
\text { area, } \\
\text { education } \\
\text { level and } \\
\text { language of } \\
\text { training. }\end{array}$ \\
\hline
\end{tabular}

It should be noted that due to a strong pressure caused by the public administration reforms and reduction in public funding for tertiary education, more and more EU countries 
are adhering to the trend of allocating public funds to universities through innovative solutions. Below is presents the existing experience of European countries for each of the financial autonomy elements described above.

Financial autonomy possibilities of european tertiary education institutions:

- line item budget (Bulgaria, Cyprus, Greece, Latvia, Lithuania, Serbia, Turkey);

- grant-based budget (Austria, Belgium, Croatia, Czech Republic, Denmark, Estonia, Finland, France, Hungary, Iceland, Ireland, Italy, Luxembourg, Malta, the Netherlands, Norway, Poland, Portugal, Romania, Slovakia, Slovenia, Spain, Serbia, Sweden, Switzerland, the United Kingdom);

- opportunity to keep a potential public fundbalance: University can save a potential balance of public funds (Austria, Belgium, Bulgaria, the UK, Croatia, the Czech Republic, Denmark, Estonia, Finland, France, Greece, Hungary, Iceland, Ireland, Italy, Luxembourg, Malta, the Netherlands, Norway, Poland, Slovakia, Slovenia, Spain, Sweden, Switzerland), University cannot save a potential balance of public funds (Cyprus, Latvia, Lithuania, Portugal, Hungary, Turkey, Serbia);

- tuition fee: no tuition fee (Austria, the Czech Republic, Denmark, Finland, Iceland, Malta, Norway, Slovakia, Sweden, Cyprus, Greece, Slovenia), the government sets the tuition fee as a fixed amount (Belgium, Bulgaria, France, Ireland, the Netherlands, Slovenia, Spain, China, Turkey); Universities set tuition fees, but authorities fix the maximum value (Italy, the UK, Romania), Universities set tuition fees (Croatia, Estonia, Greece, Hungary, Latvia, Luxembourg, Romania, the UK), tuition fees are set on the basis of interaction between universities and public authorities (Cyprus, Belgium, Lithuania);

- opportunity to take up a loan: Universities can borrow funds (Austria, Belgium, Croatia, Cyprus, the Czech Republic, Denmark, Estonia, France, Ireland, Italy, Latvia, Luxembourg, the Netherlands, Norway, Poland, Romania, Slovakia, Spain, Sweden), Universities cannot borrow funds (Belgium, Finland, Germany, Greece, Hungary, Iceland, Lithuania, Malta, Portugal, Slovenia, Switzerland, Turkey);

- ability to obtain a loan in the financial market: Universities can obtain an interest-bearing loan in the financial market (Austria, Belgium, Czech Republic, Denmark, Estonia, Hungary, Italy, Latvia, Luxembourg, Serbia, Spain, the UK), Universities cannot obtain a loan in the financial market (Belgium, Bulgaria, Cyprus, Finland, France, Denmark, Ireland, Latvia, Malta, the Netherlands, Norway, Poland, Portugal, Romania, Slovenia, Switzerland, Turkey);

- ownership of university buildings: university (Belgium, Croatia, the Czech Republic, Estonia, Greece, Ireland, Italy, Latvia, Malta, the Netherlands, Norway, Poland, Portugal, Romania, Slovenia, Spain), public authorities (Belgium, Bulgaria, Denmark, Hungary, Lithuania, Luxembourg, Turkey,
Serbia), state-owned real estate companies (Austria, Finland, Germany, Sweden), variations (depending on the situation) (France, Iceland, Slovakia, Switzerland);

- sale of university real estate: universities can sell real estate they own (Belgium, the Czech Republic, Estonia, Italy, the Netherlands, Spain, China, the UK), sale of real estate requires approval of the state authorities (Croatia, Cyprus, Iceland, Ireland, Latvia, Malta, Norway, Poland, Portugal, Romania, Slovenia, Slovakia), universities cannot sell property they own (Greece) [10].

Financial autonomy means that universities should work to diversify their income sources. Thus, according to the EUDIS project on diversifying income streams of the European University Association [19], on the average, European universities receive almost three-quarters of their funding from public sources, which guarantees some stability in the long term.

It should be noted that the trend towards university autonomy does not mean their independence from the state: in most OECD countries, authorities provide a significant share of university income, which is the main lever of government influence on the processes of university reform and the main tool for achieving positive results in the field of education. Funding schemes for tertiary education differ across countries in the degree of covering the TEI education cost from public sources, in the mechanism for potential student selection, level of TEIs' autonomy in determining tuition fees, inclusion of private TEIs in the system of public funding, etc. The average value of public expenditure on higher education in OECD countries makes up $70 \%$ of the total expenditure. For Ukraine, public expenditure on education amounted to $85 \%$ of the total expenditure in 2013, therefore it was part of the group of countries with the above average index, which included Belgium, Slovenia, Germany, Estonia, Poland, Turkey, the Czech Republic, etc. Compared to 2013, the indices of public expenditure on tertiary education for OECD countries were almost identical and showed insignificant dynamicsin 2014. Thus, the index of public expenditure on tertiary education in OECD countries accounted for the same $70 \%$ of the total expenditure, with households accounting for $21 \%$ and other private funding sources making up 9\% [15]. In 2012, this index for Ukraine, (the share of public expenditure in tertiary education funding) accounted for $69.6 \%$ respectively [15], which is almost identical to the average index for OECD countries but is lower than the average index for $22 \mathrm{EU}$ countries $(79 \%)$.

The share of education expenditure in GDP tends to fluctuate, within $1.5 \%$ towards an increase in expenditure as well as towards a reduction. Some countries, namely the United Kingdom, Sweden, Germany, Luxembourg, Italy, Liechtenstein, Slovakia, Croatia, Finland, Switzerland and Japan, show an increase in the share of expenditure on education in GDP, while some advanced economies and developing countries show a decrease in this share (Belgium, Denmark, France, Norway, Latvia, Lithuania, etc.).

In the average index of expenditure on tertiary education in $22 \mathrm{EU}$ countries, which accounts for $1.4 \%$ of GDP, funding from budgets of different levels (public funding) makes up $1.1 \%$ of GDP, while funding from private sources 
only accounts for $0.3 \%$ of GDP (Table 2) [20]. Considering the same average index at the OECD level, which makes up $1.6 \%$ of GDP, we can see that $1.1 \%$ of GDP is provided by the budget; private sources only account for $0.5 \%$ of GDP [15]. For Ukraine, the expenditure on tertiary education amounted to $1.8 \%$ of GDP in 2014, which was higher than the average share of expenditures in OECD countries.

TABLE II. PUBLIC EXPENDITURE ON TERTIARY EDUCATION (BACHELOR, MASTER AND DOCTORAL PROGRAMMES, INCLUDING RESEARCH AND SCIENTIFIC DEVELOPMENTS), \% OF GDP

\begin{tabular}{|l|c|c|c|}
\hline Countries/year & $\mathbf{2 0 1 2}$ & $\mathbf{2 0 1 3}$ & $\mathbf{2 0 1 4}$ \\
\hline Belgium & 1.278 & 1.333 & 1.334 \\
\hline the Czech Republic & 1.183 & 1.074 & 0.983 \\
\hline Denmark & 1.513 & 1.607 & 1.608 \\
\hline Germany & 1.050 & 1.047 & 1.059 \\
\hline Estonia & nd & 1.888 & 1.674 \\
\hline Ireland & nd & 1.144 & 0.828 \\
\hline Spain & nd & 0.921 & 0.903 \\
\hline France & nd & 1.203 & 1.212 \\
\hline Italy & 0.720 & 0.752 & 0.727 \\
\hline Latvia & 0.973 & 1.123 & 0.973 \\
\hline Lithuania & 1.312 & 1.280 & 1.289 \\
\hline Luxembourg & nd & 0.519 & 0.489 \\
\hline Hungary & 0.678 & 0.818 & 0.659 \\
\hline the Netherlands & 1.207 & 1.223 & 1.231 \\
\hline Austria & 1.678 & 1.662 & 1.633 \\
\hline Poland & nd & 1.248 & 1.184 \\
\hline Portugal & 0.778 & 0.859 & 0.892 \\
\hline Slovenia & 1.057 & 1.025 & 0.964 \\
\hline Slovakia & 0.806 & 0.846 & 0.860 \\
\hline Finland & 1.782 & 1.743 & 1.717 \\
\hline Sweden & 1.512 & 1.526 & 1.520 \\
\hline
\end{tabular}

Sources: [15]

The most debatable issue of today is how much the state should support the efforts of a particular individual in obtaining tertiary education. Although the major share expenditure and investment in tertiary education is still provided through public funding, the role of private sources is becoming increasingly visible and crucial at separate levels of education. Thus, the equilibrium between public and private funding of tertiary education in OECD countries varies considerably, with private funding being mainly provided by households. This fact proves motivation of individuals regarding tertiary education. Thus, among OECD countries, the financial return on tertiary education for men is approximately US $\$ 258,400$ on the average over the employment period compared to men who obtained secondary or secondary vocational training [15]. It should be noted that the prevalence of public expenditure by education levels, should be based on overall objectives of economy and clearly direct employment potential depending on these objectives: allocation of increased proportion of expenditure to secondary education and secondary vocational training rather than to tertiary education.

In Ukraine, the share of household expenditure is declining at a much faster rate than expenditure based on other sources of funding. Thus, the shares of households and private sector in tertiary education funding accounted for $17.6 \%$ and $17.5 \%$ respectively compared to 2013 , while the state budget expenditure decreased by $13.6 \%$, local budget expenditure - by $13.0 \%$. In the context of a consistently low share of private sector participation $(0.75 \%$ of GDP), the given trends towards tertiary education funding indicate the difficulties the private sector is faced with in funding employees' education as well as low involvement of the private sector in research and innovation projects in the university environment. Investments in education are justified as they have a positive effect: it is the countries that understand this concept and invest significantly that lead in terms of GDP. Investments in education are strategically important both for the country and the individual. Considering an important role of education in the Ukrainian national economy development, further we investigated the characteristics of the relationship between the education expenditure and GDP.

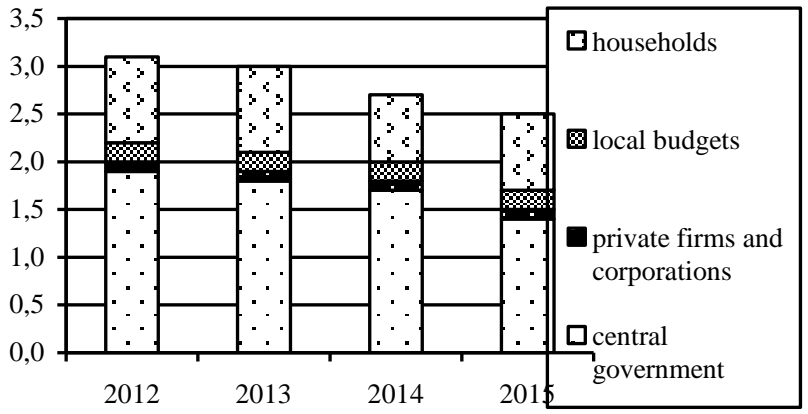

Fig. 1. Allocation of expenditure on tertiary education (covering the first and second stages of tertiary education in Ukraine, by funding sources**, 2012-2015, \% of GDP

**2012-2013: the GDP data is compiled according to the 2008 SNA methodology: 2014-2015: the GDP data is compiled according to 2008 SNA methodology (excluding the temporarily occupied territory of the Autonomous Republic of Crimea and Sevastopol and part of the ATO Zone.

Based on sources [20, 21]

On the basis of the statistical data of the GDP in Ukraine and expenditure of the consolidated budget on education in 2006-2015, we built a correlation field, which enables us to graphically assess the relationship closeness between the indices (Figure 2). We can see that the empirical line goes to the right and up, which means that the relationship between the indices is straightforward. To estimate the relationship between GDP and education expenditure, we constructed a correlative linear regression model. According to the initial data of 2006-2015 [20], using MS Excel, we made calculations and obtained the values of the equation parameters for the correlative linear regression.

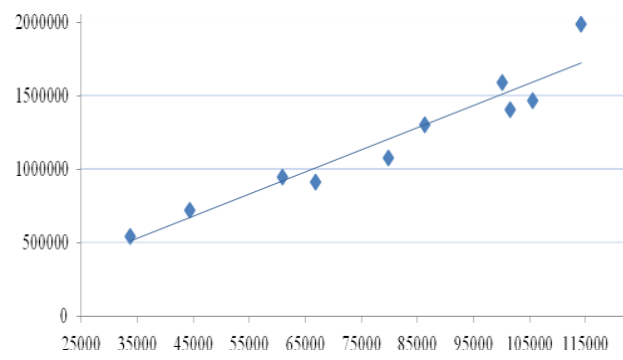

Budget expenditure on education GDP

Fig. 2. Fig. 2. Correlation between the changes in GDP and changes in the budget expenditure on education

Made by the authors based on sources [20]

The regression dependence of Yindex on Xindex is expressed by the following equation:

$$
Y=-24324,3363+15,3708204 \times X
$$


where $X$ - the amount of expenditure of the consolidated budget on education, UAH million;

$$
Y \text { - GDP, million. }
$$

Number equations consecutively. The obtained R-square determination coefficient $(91.98 \%)$ and standardized Rsquare determination coefficient $(90.97 \%)$ indicate a close relationship between the factor variable and effective index. The variation of the considered $\mathrm{Y}$ dependent variableby $90.97 \%$ is determined by the change in $\mathrm{X}$ factor variable. Since for equation (1) the determination coefficient is higher than $80 \%$, the equation is adequate and can be applied in practice. The parameter value at the independent variable $(\beta$ $=15,3708204$ ) in the regression equation (1) shows that the increase in the consolidated budget expenditure on education by UAH 1 million will result in the GDP growth by UAH 15,3708204 million. The GDP sensitivity to changes in the volume of the consolidated budget expenditure on education is measured by the coefficient of elasticity, which is $\mathrm{E}=1.02$ for the resulting model (1) and shows that an increase in the expenditure of the consolidated budget on education by $1 \%$ results in an increase in the GDP by $1.02 \%$.

\section{CONCLUSIONS}

In almost all the countries, except for Canada and the Netherlands, households share of private education funding at primary, secondary and secondary vocational levels is the largest. Households also contribute the largest share to tertiary education funding, except for the Czech Republic, Finland and Switzerland. Other sources of non-state funding for TEIs include: contracts with private partners (especially for universities of technology), charitable funding, income from services (conference room management, catering and housing, educational and consulting services, cultural services), international public funding (structural funds account for the largest share of approximately 40\%) and funds for research and development programs (approximately 33\%). To assess the relationship between the GDP and budget expenditure on education, a correlative linear regression model was built. The obtained dependence indicates the existing direct relationship between the indices, in particular, an increase in the consolidated budget expenditure on education by $1 \%$ results in an increase in the GDP by $1.02 \%$.

\section{REFERENCES}

[1] Resolution of the Cabinet of Ministers of Ukraine. (2010, August 27). No. 796 «On amendments to the Resolution of the Cabinet of Ministers of Ukraine». [Online]. Available: http://zakon0.rada.gov.ua/laws/show/305-2015-\%D0\%BF

[2] Annual Public Report-2013. CNFIS. Higher education funding and necessary improvement actions. [Online]. Available: http://www.cnfis.ro/wp-content/uploads/2014/11 /CNFIS-reportpublic2013-2014-08-04_en_ultim.pdf. Accessed on: August 1, 2019.

[3] T. I. Yefymenko, Taxes in the institutional system of modern economy, Kyiv, Ukraine: NASU Institute for Economics and Forecasting, 2011.

[4] T. I. Yefymenko, S. L. Londar and Yu. B. Ivanov, The development of the tax system of Ukraine: transformation of the simplified tax system, Kyiv, Ukraine: DNNU «Academy of Financial Management», 2011.

[5] O. I. Kotykova, «Financing of the education system in Ukraine: state and trends», Herald MNAU, no. 4 (1), pp. 19-24, 2012 [in Ukrainian].

[6] Autonomy of Ukrainian universities: analysis and action plan, European University Association, 2011. [Online]. Available: http://www.euroosvita.net/prog/data/attach/4519/athena-analysis-androadmap-for-ukraine-ukr.pdf. Accessed on: August 10, 2019.

[7] T. Estermann and T. Nokkala (2009), «University autonomy in Europe I: Exploratory study, EUA, Brussels, Belgium», [Online]. Available:

http://www.rkrs.si/gradiva/dokumenti/EUA_Autonomy_Report_Final .pdf. Accessed on: August 10, 2019.

[8] European Centre for Strategic Management of Universities , Funding higher education: a view across Europe, 2010. [Online]. Available: https://uniko.ac.at > modules > download. Accessed on: August 10, 2019.

[9] European University Association, Designing strategies for efficient funding of higher education in Europe, 2013. [Online]. Available: http://www.eua.be/Libraries/publication/DEFINE_final. Accessed on: July 20, 2019.

[10] European University Association, University autonomy in Europe. Exploratory study, 2009. [Online]. Available: http://www.salvatorevassallo.org/wpcontent/uploads/2008/11/file_Do ssier_Universita_EUA_Autonomy_Report_Final.pdf. Accessed on: July $20,2019$.

[11] T. Estermann and E. B. Pruvot, Financially Sustainable Universities II: European Universities Diversifying Income Streams, EUA, Brussels, Belgium, 2011. [Online]. Available: https://eua.eu/resources/publications/405:financially-sustainableuniversities-ii-european-universities-diversifying-incomestreams.html. Accessed on: July 21, 2019.

[12] J. B. Koelman, The funding of universities in the Netherlands: developments and trends, Higher education, no. 19 (35), pp. 127-141, 1998. [Online]. Available: at: https://doi.org/10.1023/A:1003169219210. Accessed on: June 29, 2019 .

[13] J. Salmi and A. M. Hauptman, «Innovations in Tertiary Education Financing: A Comparative Evaluation of Allocation Mechanisms», Education Working Papers Series, vol. 4, 2006. [Online]. Available: http://siteresources.worldbank.org/EDUCATION/Resources/278200$1099079877269 / 547664-$

1099079956815/Innovations_TertiaryEd_Financing.pdf. Accessed on: June 21, 2019.

[14] The World Bank, Education Working Paper, Series, no. 4, 2006. [Online]. Available: http://siteresources.worldbank.org/EDUCATION/Resources/278200$1099079877269 / 547664$

1099079956815/Innovations_TertiaryEd_Financing.pdf. Accessed on: May 2, 2019.

[15] The Organisation for Economic Co-operation and Development (OECD), 2010, 2016, 2017. [Online]. Available: http://www.oecd.org/. Accessed on: July 2, 2019.

[16] European University Association, The EUA Funding Forum 2012, 2012. [Online]. Available: http://www.eua.be/activitiesservices/events/past/2012/eua-funding-forum/home.aspx. Accessed on: May 20, 2018.

[17] M. Paunescu, Education revenues and expenditures in Romania, Proceedings of the speech at the Working Meeting in the Ministry of Education and Science of Ukraine on the issue of HEI funding system reform, Kyiv, Ukraine, 2017.

[18] A. Pliksnys, Education revenues and expenditures, Proceedings of the speech at the Working Meeting in the Ministry of Education and Science of Ukraine on the issue of HEI funding system reform, Kyiv, Ukraine, 2017.

[19] European University Association, EUDIS: European Universities Diversifying Income Streams (2008-2011), 2011. [Online]. Available: http://www.eua.be/activities-services/projects/past-

projects/governance-autonomy-and-funding/eudis.aspx. Accessed on: May 25, 2019.

[20] Official Website of the State Statistics Service of Ukraine, 20162019. [Online]. Available: http://www.ukrstat.gov.ua/. Accessed on: August 2, 2019.

[21] Ye. Stadnyi, Education in Ukraine - 2015: Illustrated collection from CEDOS, pp. 5-7, 2015. [Online]. Available: http://www.cedos.org.ua/uk/osvita/zvit-osvita-2015. Accessed on: August 1, 2019), [in Ukrainian]. 